\title{
Farmers Characteristics and Its Influencing on Loans Resettlement Decision in Sri Lanka
}

\author{
Thayaparan Aruppillai ${ }^{1} \&$ Paulina Mary Godwin Phillip ${ }^{2}$ \\ ${ }^{1}$ Faculty of Business Studies, Vavuniya Campus of the University of Jaffna, Sri Lanka \\ Correspondence: Thayaparan Aruppillai, Vavuniya Campus of the University of Jaffna, Sri Lanka. Tel: \\ 94-7-7614-3582. E-mail: aruppillaithayaparan@yahoo.com
}

Received: January 7, 2014

Accepted: January 23, 2014

Online Published: March 25, 2014

doi:10.5539/ijef.v6n4p110

URL: http://dx.doi.org/10.5539/ijef.v6n4p110

\begin{abstract}
This study investigates the impact of socio-economic characteristics of the farmers and its impact on their loans resettlement behavior in the People's Bank, Puttalam branch in Sri Lanka. Secondary data were collected from the bank officials and the data were analyzed with 100 applicants who are cultivating paddy as a major crop and other field crops during the Maha and Yala season 2011/2012. This study was analyzed using descriptive statistics, Tobit model and in addition to that elasticity of the loan repayment ratio also measured. The estimated Tobit regression model indicated that family members and secondary education were significantly positive influence on the farmers' repayment behavior while loan disbursement has negative influence on their behavior in Sri Lanka. Other independent variables namely gender, age, civil status, major crops, income and higher level of education of the beneficiaries were not statistically significant influence on the farmers' behavior in the above bank branch in Sri Lanka. The elasticity of the loan repayment performance for the variables also were calculated at the mean values and according to that number of family members, size of loans and secondary education were statistically significant. The overall results revealed that, the bank managers should considered the above characters of the borrowers to increase the probability of repayment ratio and thus it will help them to improve the efficiency of lending decision of the bank loans in future.
\end{abstract}

Keywords: loan repayment performance, Tobit model, loan disbursement, borrowers

\section{Introduction}

Agriculture is an important sector as a major source of food and nutrition, income and employment opportunities for the low income peoples in Sri Lanka. To develop and improve the productivity of agriculture, the government providing loans to the farmers through various micro finance institutions such as banks. Thus, agricultural credit is one of the main tools to improve the standard of living of the farmers and also it will help to enhance the production capacity in the farm. Since 1973/74, the People's Bank in Puttalam branch was grant the loans to small holder farmers for various agricultural productions especially for the paddy and other cash crops such as banana, papaya, mushroom, onion and chilli for the purpose of sowing, harvesting, processing and storage. By providing loans for the farmers encourage them to engage their production activities and improve their standard of living. The inability of the borrowers to repay the borrowed funds in accordance with the loan terms constitutes a major issue to the banks and the major problems facing by the banks are higher default ratio and low benefits. Apart from the challenges to reaching out the poor in offering the microcredit loan, the microfinance institutions such as state owned banks and other micro finance institutions also having challenges with loan repayment. The main effect of default is that it reduces the validity and capability of financial institutions such as banks. An increasing trend of default ratio of the loans by the borrowers has been identified as one of the problems in the study area.

This paper aims to empirically analyze the socio-economic characteristics of the farmers that influence on their repayment behavior in the People's Bank. Findings of this study will help the bank managers and officers to identify the factors that influence on the farmers resettlement behavior and thereby it will useful for them to make their improvement and policy changes in the loans in the future.

George, Ugbomeh, Felix, Victor and Albert (2007) identified that women headed family, rate of interest and number of family members have negative impact on loan repayment ratio of women farmers while price of the farm products and commitment have positive impact on their behavior in Bayelsa State, Nigeria. 
Onyenucheya and Ukoha (2007) discovered that amount of loan borrowed, annual income and distance between home and loan source were key determinants of repayment behavior in Nigeria. Another research carried out by Olagunju and Adeyemo (2007) and they examined the factors of repayment concert among small farmers in Southwestern in Nigeria. Their results showed that, experience of farmers, location of farm, costs of loan, number of visits, and education of the farmers were main causes to determine the beneficiaries' performance in all the institutions in Nigeria.

Afolabi (2008) examined the characters that discriminate loan defaulters from non-defaulters in Nigeria by using discriminant analysis. He has concluded that, age of the borrowers, income from farm, net income from farming activities, rate of interest and number of farming experience in years were discriminate the defaulters from non-defaulters.

According to Mohammad and Hooman (2009), find out that interest rate on their loans is significantly impact on repayment of agricultural loans in Khorasan-Razavi Province of Iran.

Amjad, Farzand and Khyber (2009) examined the impact of farmers' characteristics on repayment for agricultural growth in Pakistan. The regression results showed marital status, type of farm, number of credit received were significantly influence on repayment of their loans.

Acquah and Addo (2011), found that loan repayment have positive relations with education, income from fishing, experience of fishing and loan size. But age of the borrower and their amount of investment inversely affected on the repayment ratio. The regression results suggest that income, size of loans and the investment level were significantly influenced on the amount of loan repaid in Ghana.

According to Onyeagocha, Chidebelu, Okorji, Ukoha, Osuji and Korie (2012), they found that training, amount of loans and experience of the loan officers were significant factors in determining the loan repayment of Microfinance Institutions in Southeast States of Nigeria.

\section{Methodology}

This research carried out in Puttalam district which is located in North western province of Sri Lanka. Agricultural development mainly depends on the uses of loans and its facilities given by the micro finance institutions such as banks. It may help the borrowers to use modern technologies and advanced practices in their field. In this point of view People's bank playing a significant role to provide the loans for farmers to enhance the productivity of their agricultural yield. Purpose of this study is to evaluate the impact of socio-economic factors that influence on loan repayment behavior of the borrowers in the branch of People's bank, Puttalam district in Sri Lanka. A total of 100 applicants were collected from the bank who were received the loans for agricultural production purposes during Maha and Yala season in 2011/12. The bank has received totally 250 loan applicants and out of these applicants, only 100 were fully approved by the bank. Thus, the 100 applicants were used as a sample in this study.

Descriptive statistics of the dependent and independent variables were used to find out the mean values for overall applications. The determinants of the loan repayment problems were analyzed using Tobit model. In addition to that, measurement of elasticity after Tobit model also was estimated. The dependent variable is a censored and limited between lower value of zero and upper value of one. Therefore, Tobit model is more useful and it has been used more specially in social sciences. The dependent variable of the model is the repayment ratio which is calculated as the ratio of amount of loan repaid to the total amount of loans borrowed from the bank. Because of the nature of the dependent variable, a two-limit Tobit model has been chosen as an appropriate model than other models.

The performance of the borrowers in repaying decisions was analyzed using the following standard Tobit model as below:

$$
Y_{i}^{*}=X_{i} \beta+\varepsilon_{i}, Y_{i}=Y_{i}^{*} \text { if } Y_{i}>0, Y_{i}=0 \text { if } Y_{i} \leq 0
$$

Where $\mathrm{Y}_{\mathrm{i}}$ is the censored dependent variable which can be observed, $\mathrm{X}_{\mathrm{i}}$ is the vector of independent variables, $\beta$ is the vector of coefficients, and the $\varepsilon_{\mathrm{i}}$ 's are error term. The marginal effects of the independent variables could be used to identify the effect of nine independent variables on loan repayment behavior. In Tobit model, there are three marginal effects are applicable and they were derived as below:

$$
\begin{gathered}
\frac{M E(y * / x)}{M x}=\beta \\
\frac{M E(y / x)}{M x}=\varphi \beta
\end{gathered}
$$




$$
\frac{M E(y / y>0 \chi)}{M x}=\varphi \beta
$$

Where,

$\delta(\alpha)=\lambda(\alpha)(\lambda(\alpha)-\alpha), \lambda(\alpha)=\downarrow(\alpha) /(1-\Phi(\alpha))$, and $\alpha=-(x \beta \sigma)$ and only for censored dependent variable Y can be explained in terms of marginal effects of each independent variable.

Decisions of repayment for each borrower assumed depend on their feeling to resettle the loans. Gustafson indicated that borrower's decisions on repayment depend on their utility function. If $j$ refers the size of loans and it coded as $j=1$ higher amount of loans and $j=2$ for less amount of loans, then the preferences of the $i^{\text {th }}$ borrower, is shown as $\mu\left(\left(\mathrm{M}_{\mathrm{ji}}, \mathrm{A}_{\mathrm{ji}}\right)\right.$. Thus, the satisfaction of different sizes of loans depends on $\mathrm{M}$, which is a vector of farmers attributes to the loan beneficiary and $\mathrm{A}$, is a vector of attributes with respect to the sizes of loan obtained. Although the utility function is unobserved, a linear relationship is postulated between the utility derivable from a $\mathrm{j}^{\text {th }}$ loan size and the vector of observed farm and farmers characteristics such as gender, age, civil status, type of crops, size of loans and a disturbance term having a zero mean,

$$
e j: \mu_{j i}=\beta_{i} X_{i}+e_{j i} j=1,2: i=1, \ldots, n
$$

and

$$
X_{i}=F_{i}\left(M_{i}, A_{i}\right)
$$

Borrowers are assumed to repay their loan size that gives them the highest utility. Thus, equation (6) does not restrict the utilities $\mu_{\mathrm{ji}}$ are random, the $\mathrm{i}^{\text {th }}$ borrower will select the alternative.

$\mathrm{j}=1$ if $\mu_{1 \mathrm{i}}>\mu_{2 \mathrm{i}}$ or if the unobservable random variable

$$
Y^{*}=\mu_{1 i}-\mu_{2 i}>0
$$

Interpretation of the dependent variable in the model is in terms of probability with a given $\mathrm{X}_{\mathrm{I}}$ and the probability that $\mathrm{Y}_{\mathrm{i}}=1$ (i.e. that the borrower repays the loan) is a function of the independent variables:

$$
\begin{aligned}
P_{i} & =P_{r}\left(Y_{i}=1\right)=\operatorname{Pr}\left(\mu_{1 i}>\mu_{2 i}\right) \\
& =P_{r}\left(\beta_{1} X_{i}+e_{1 i}>\beta_{2} X_{i}+e_{2 i}\right) \\
& =P_{r}\left[e_{1 i}-e_{2 i}>X i\left(\beta_{2}-\beta_{1}\right)\right] \\
& =P_{r}\left(\mu_{i}>X_{i} \beta\right)
\end{aligned}
$$

Therefore,

$$
P_{i}=P_{r}\left(Y_{i}=1\right)=F_{i}\left(X_{i} \beta\right)
$$

Where;

$\mathrm{P}_{\mathrm{r}}=$ a probability functions;

$\mu_{\mathrm{i}}=$ a random disturbance term $\left(\mathrm{e}_{1 \mathrm{i}}-\mathrm{e}_{2 \mathrm{i}}\right) ; \mu \mathrm{i} \sim \mathrm{N}\left(0, \sigma^{2} 1\right)$;

$\mathrm{X}=$ the $\mathrm{n} \times \mathrm{k}$ matrix of the explanatory variables;

$\beta=\mathrm{k}=\mathrm{k} \times 1$ vector of parameters to be estimated;

$F\left(X_{i} \beta\right)=$ cumulative distribution function for $\mu_{i}$ evaluated at $X_{I} \beta$.

Thus, probability of repayment made by a borrower depends on the vector of independent variables, unknown parameters and error term. However, equation (8) cannot be estimated directly without knowing the form of F. It is the distribution of $\mu_{\mathrm{i}}$ that determines the distribution of $\mathrm{F}$. therefore, if $\mu_{\mathrm{i}}$ is normal, $\mathrm{F}$ will have a cumulative normal distribution. The functional form of $\mathrm{F}$ can be specified as a linear combination of observable explanatory variables as:

$$
Y^{*}{ }_{i}=\beta X_{i}+\mu_{i}
$$

For ith borrower it can be shown as below:

$$
Y i=\beta_{0}+\beta_{1} X_{1 i}+\beta_{2} X_{2 i}+\ldots+\beta_{N} X_{N} ; i=1,2, \ldots, N
$$

Such that

$$
Y_{i}=\left\{\begin{array}{l}
0 \text { if } Y_{i}^{*} \leq T \\
Y_{i}^{*} \text { if } 0<Y_{i}^{*}<1 ; \quad(i=1,2, \ldots, n) \\
1 \text { if } Y_{i}^{*}>T
\end{array}\right.
$$


Where,

$Y_{i}=$ observed dependent variable e.g. the amount of loans repaid by the $i^{\text {th }}$ borrower.

$\mathrm{Y}^{*}{ }_{\mathrm{i}}=$ continuous dependent variable (Ratio of loan repaid);

$\mathrm{T}=$ non-observable threshold (cut-off) point;

$\mathrm{N}=$ number of observations.

Thus, Tobit model was applied to analyze the farmers' characteristics and its influencing on loans resettlement decision in Sri Lanka.

\section{Data Analysis}

Data were analyzed using three econometric techniques such as descriptive statistics, Tobit regression model, and estimated elasticity after Tobit. In Tobit model repayment performance and the explanatory variables. Repayment performance treated as the dependent variable and nine variables were proposed as the independent in the study. The coefficients of each variable have their sign as expected based on economic theory, previous studies.

$$
Y=\beta_{0}+\beta_{1} X_{1}+\beta_{2} X_{2}+\beta_{3} X_{3}+\beta_{4} X_{4}+\beta_{5} X_{5}+\beta_{6} X_{6}+\beta_{7} X_{7}+\beta_{8} X_{8}+\beta_{9} X_{9}+e
$$

Where

$Y=$ Repayment ratio is as the censored dependent variable and it can be measured as,

$$
\begin{aligned}
Y & =\frac{\text { Amount of loans repaid }}{\text { Total disbursement of loans }} \times 100 \\
& =0 \text { if other wise }
\end{aligned}
$$

$X_{I}=$ Sex of the beneficiaries dummy ( 0 for Female, 1 for Male);

$X_{2}=$ Age of the beneficiaries in years;

$X_{3}=$ Civil status dummy ( 0 for single, 1 for married);

$X_{4}=$ Size of family in numbers;

$X_{5}=$ Amount of loan disbursed in rupees;

$X_{6}=$ Types of crops dummy ( 0 for other crops, 1 for paddy);

$X_{7}=$ Secondary education dummy ( 1 for secondary, 0 for otherwise);

$X_{8}=$ Higher education dummy ( 1 for higher, 0 for otherwise);

$X_{9}=$ Monthly income in rupees;

$e=$ Error term.

The dependent variable loan repayment ratio is a censored variable at a lower bound of 0 and an upper of 100 .

\section{Results and Discussions}

Descriptive statistics of the dependent and independent variables of the sample which were used in this study is shown in Table 1. It was shown that average 44.5 loans were repaid and sex distribution of the borrowers showed that nearly $68 \%$ of the borrowers were male and remaining $32 \%$ of them were female. The age of the borrowers varied between twenty one and fifty years old with a mean of thirty five years for all the respondents. It suggests that the middle aged farmers are expected to be work economically active with energy and thus, they should be willing to adopt new techniques and innovations to increase the productivity in their farming. Since traditional agricultural production systems still rely on rudimentary implements powered by human used it means that very old farmers will face severe energy constraints and will be less productive than the younger and energetic farmers. Further, the above results showed that majority $(86 \%)$ of the borrowers was married and on average they have 4 members in their family. On average Rs77450/= were disbursed for them for purpose of paddy cultivation (47\%) and other crops (53\%). The distribution of educational attainment showed that $61 \%$ of the borrowers had primary education while $37 \%$ had secondary education. Only $2 \%$ of them attained higher education in the study area. 
Table 1. Results of the descriptive statistics of the sampled beneficiaries

Source: N=100, Survey data.

\begin{tabular}{lll}
\hline Variables & & Mean \\
\hline Repayment ratio & & 44.5 \\
Sex & Male & 0.68 \\
& Female & 0.32 \\
Age & & 35.01 \\
Civil status & Single & 0.14 \\
& Married & 0.86 \\
Family Member & & 3.68 \\
Loan amount & & 77450 \\
Major crops & Paddy & 0.47 \\
& Other crops & 0.53 \\
Income & & 15875 \\
Education & Primary & 0.61 \\
& Secondary & 0.37 \\
& Higher & 0.02 \\
\hline
\end{tabular}

The estimated Tobit results of the variables were displayed in Table 2.

Table 2. Results of the Tobit model

\begin{tabular}{lllll}
\hline Repayment ratio & Coefficient & Std. Err & t & P>t \\
\hline Gender & -2.831 & 6.234 & -0.45 & 0.651 \\
Age & 0.6158 & 0.412 & 1.49 & 0.139 \\
Civil status & -4.546 & 8.929 & -0.51 & 0.612 \\
Family members & 6.866 & 2.21 & 3.11 & $0.003^{*}$ \\
Loan amount & -0.00014 & 0.00006 & -2.34 & $0.022^{* *}$ \\
Major crops & -7.498 & 6.086 & -1.23 & 0.221 \\
Income & 0.00031 & 0.00034 & 0.92 & 0.36 \\
Secondary & 18.802 & 6.1 & 3.08 & $0.003^{*}$ \\
Higher & 26.27 & 18.798 & 1.4 & 0.166 \\
Constant & 6.479 & 15.491 & 0.42 & 0.677 \\
\hline
\end{tabular}

Source: Survey data, * Significant at $1 \%$ level; ** Significant at $5 \%$ level.

For three levels education, only two dummies were used to avoid the dummy variable trap and primary education considered as base category.

Log likelihood $=-424.79632$;

Number of Observations $=100$;

$\operatorname{LRChi}^{2}(9)=21.82$;

Prob $>$ chi $^{2}=0.0095$;

Pseudo $\mathrm{R}^{2}=0.0250$.

According to the results, it showed that out of nine independent variables only three independent variables such as family members, amount of loan disbursed and secondary education were statistically significant at $5 \%$ level and rest of the other variables was not statistically significant.

The negative insignificant dummy variable for gender showed that female borrowers have a better repayment performance than males. In other words, the probability of loan default ratio for male farmers was higher than women farmers. The fact that on average women have lower default probabilities could be explain by their positive behavior in repaying the loans and women in the society usually posses more concern on their disciplined behavior and scare and they are not ready to lose their good identity in the society. But compare with female farmers, male farmers were not much responsible and discipline to repay their loans. Since male borrowers have a higher loan default ratio, the bank should consider financial commitment in their family and also check the male farmers' 
financial obligations of loans in any other financial institutions before issuing a new loan for male borrowers.

The coefficient for age of the borrowers have positive impact on the repayment performance reveals that as age of the beneficiaries increases their repayment performance of loan also increases. But it is not statistically significant.

Negative sign recorded by the coefficient of the variable civil status indicates that the borrowers who have married have less loan repayment performance than single borrowers. Due to the family expenditures, married borrowers may use their loans for other consumption purposes than cultivation activities. Family members have positive sign indicates that as household size increases, the proportion of loan repayment also increases. This proved that the farmers who have their family members with other jobs were ably for prompt to repay their loans than who are the farmers with their family members engaging only agriculture. Because of other earning income sources from the family member who are engaged with other jobs along farming, they also give their corporation to settle the loans.

The negative sign of the loan amount showed that as they received more and more amounts of loans from the bank, it may encourage spending their loans on other expenditures than production purposes. Negative sign of the coefficient for major crops was indicated that the farmers who are cultivating other cash crops that would have a better repayment performance than who are cultivating paddy as the major crops in their land. Farmers, who are cultivating other crops such as coconut, mushroom, papaya, pineapple and vegetables in their lands have better production and marketing facilities gives better profit. Thus they are not much facing the problem to repay their loans in time. Thus, the borrowers involved in paddy cultivation were more likely to have a higher default ratio than who are the farmers involved in other cash crops. Since the farmers engaged in paddy cultivation have a higher probability of default problems, the bank needs to consider giving flexibility in loan repayments to borrowers who receive income irregularly caused by inadequate marketing facilities and price fluctuations. Income of the borrowers has positive impact on repayment performance indicates that the farmers who have higher income that provides more capacity to repay their loans than who has less income.

There is no statistically significant impact on repayment performance with high level of education. However there is a highly positive significant relations between secondary education and the performance of resettlement behavior exhibited that farmers who have secondary education encourage them to adopt improved technologies and new practices that could enhance a better yield from their farming. It confirmed that their educational knowledge and skills help them easily and quickly to adopt new advanced techniques and practices in their farming. Therefore, educated farmers prefer to avoid their default ratio and they considered that repaying the loans in time creates good credit worthiness for them.

As shown in Table 3, elasticity of the loan repayment performance for the variables was calculated at the mean values. They show that the elasticity of loan repayment performance increase with age, family members, income, secondary and higher educational levels while gender, civil status, amount of loans and major crops will decrease the elasticity of loan repayment performance in the bank. For the variable for gender, if the borrower is as a male, the elasticity of loan repayment performance will decrease by $0.042 \%$. As age of the borrowers' increases by $1 \%$, elasticity of repayment performance also increases by $0.47 \%$ while if the borrower is a married person, their repayment performance decreases by $0.08 \%$. Also, the elasticity of household size implies that, the average household size increases the elasticity of their repayment performance by $0.55 \%$ whereas the elasticity of loan repayment performance decreases by $0.23 \%$ for amount of loans.

Table 3. Elasticity of the loan repayment performance

\begin{tabular}{lllll}
\hline Variables & ey/ex & Std. Err & $\mathbf{z}$ & $\mathbf{P}>|\mathbf{z}|$ \\
\hline Gender & -0.0423282 & 0.09321 & -0.45 & 0.65 \\
Age & 0.4739454 & 0.31881 & 1.49 & 0.137 \\
Civil status & -0.0859513 & 0.16889 & -0.51 & 0.611 \\
Family members & 0.5554682 & 0.18096 & 3.07 & $0.002^{*}$ \\
Loan amount & -0.2399439 & 0.10336 & -2.32 & $0.020 * *$ \\
Major crops & -0.0774756 & 0.06296 & -1.23 & 0.218 \\
Income & 0.1093608 & 0.11888 & 0.92 & 0.358 \\
Secondary & 0.1529367 & 0.05021 & 3.05 & $0.002 *$ \\
Higher & 0.0115501 & 0.00829 & 1.39 & 0.164 \\
\hline
\end{tabular}

Note: $y=$ Fitted values (predict) $=45.489039$. At $1 \%$ significant level, ** At $5 \%$ significant level.

In case of types of cultivated crops, a $1 \%$ increase in the proportion of farmers who are cultivating to paddy will 
decrease the elasticity of repayment performance by $0.07 \%$. Similarly, a $1 \%$ increase in the income of the farmers will encourage them to repay their loans by $0.10 \%$.

Regarding educational levels, secondary and higher levels of education of the borrowers enhances the elasticity of loan repayment performance by $0.15 \%$ and 0.0115 respectively and as expected that they positively influences on the performance. However, level of higher education is not statistically significant.

\section{Conclusions}

This study concluded that repayment performance of agricultural loans depend on the socio-economic characteristics of the farmers in the Bank. Further this study revealed that gender, age of the farmers, civil status, major crops, income, and higher education were not statistically significant influence on the farmers' loan repayment behavior whereas family members, amount of loans disbursement and secondary education were statistically significant influence on it. Out of nine independent variables, only three variables such as family members, amount of loans issued and secondary education level were statistically significant in the sample borrowers. Descriptive statistics showed that only $10 \%$ of the borrowers were fully repaid their entire loans and $90 \%$ of them not fully repaid their loans. Further, Tobit results suggest that the provision of loans for female borrowers have better repayment performance than males. Thus, further disbursement of loans in future should default ratio than males. However in order to improve the banks overall performance and cut down loans default rates among small holder farmers in the bank, the following recommendations are tenable:

- Disbursement of the loans by the bank managers should be target to women farmers.

- Banks should show the priority to relatively aged farmers in granting loans because age contributed positively to loan repayment and credit worthiness.

- Loans should be given to farmers whose members have occupied in other jobs to ensure the effective repayment performance on time.

- Amount of loans disbursed contributed inversely to loan repayment performance, showing that relatively less amount of loans borrowers are more credit worthy than higher amount borrowers. This indicates that adequate and better visitation, regular monitoring and recovery arrangements should be necessary to improve the recovery of the loans.

- Adequate and better marketing facilities and price policies should be given by the policy makers to improve the paddy production and it will encourage the paddy farmers to repay their loans without delay.

- Efforts should be made by the farmers to improve on their income level by the way of increased production. This will enhance their ability to repay their loans on time.

- High level of preference should be given to the secondary educated farmers in loan approval.

Finally, this study revealed that, the management of the banks should consider these policy recommendations critically and possibly restructure the contents of the loan application forms issued to the farmers by placing more emphasis on the above stated farmer characteristics which promote loan repayment and credit worthiness. This might help and improve the People's bank managers to understand the factors that influence the loan repayment behavior of the borrowers and help them to improve their repayment attitudes and overall performance of the bank.

\section{References}

Acquah, H. D., \& Addo, J. (2011). Determinants of Loan Repayment of performance of fisherman: Empirical evidence from Ghana. Cercetări Agronomice în Moldova, 4(148), 89-97. Retrieved from http://www.uaiasi.ro/Cercet_Agromold/Ca4-11-08.pdf

Afolabi, J. (2008). Analysis of Loan Repayment among Small Scale Farmers in South Western Nigeria: A Discriminate Approach. Journal of Social Sciences, 17(1), 83-88. Retrieved from http://www.krepublishers.com/02-Journals/JSS/JSS-17-0-000-000-2008-Web/JSS-17-1-001-08-Abst-Text/J SS-17-1-083-08-477-Afolabi-J-A/JSS-17-1-083-08-477-Afolabi-J-A-Tt.pdf

Amjad, S., Farzand, A. J., \& Khyber, P. (2009). Impact of Farm and Farmers Characteristics on Repayment of Agriculture Credit. Abasyn Journal of Social Sciences, 4(1), 23-35. Retrieved from http://64.17.184.140/wp-content/uploads/2012/12/V4I1-3.pdf

George, M., Ugbomeh, S., Felix, O. A., Victor, I., Albert, U., \& Ofuoku, J. (2007). Determinants of Loan repayment performance among women self help groups in Bayelsa State, Nigeria. Agriculturac Conspectus Scientificus, $\quad 73(5)$, 189-195. 
http://www.researchgate.net/publication/26541302_Determinants_of_Loan_Repayment_Performance_Amo ng_Women_Self_Help_Groups_in_Bayelsa_State_Nigeria

Gustafson, C. R. (1989). Credit evaluation: Monitoring the financial health of agriculture. American Journal of Agricultural Economics, 1145-1151. http://dx.doi.org/10.2307/1243097

Gustafson, C., Bayer, R., \& Saxowsky, D. M. (1991). Credit evaluation investigating the decision process of agricultural Loan officers. Agricultural Finance Review, 55-63.

LaDue, E. L., Lee, W. F., Hanson, S. D., \& Kohi, D. M. (1992). Credit evaluation procedures at agricultural banks in the Northeast and Eastern Cornbelt. Development of Agricultural Economics Research Report, 92-93.

Mabawonku, A. F., \& Olomola, A. S. (1988). Monetary and fiscal policies in Nigeria, 1970-1985: Some Implication for Agricultural Development. Savings and Development Quarterly Review, 343-362.

Mohammad, R. K., \& Hooman, M. (2009). Factors affecting on loan repayment performance of farmers in Khorasan-Razavi province of Iran. Conference on International Research on Food Security, National Resource Management and Rural Development. Retrieved from http://www.tropentag.de/2009/abstracts/full/264.pdf

Olagunju, F. I., \& Adeyemo, R. (2007). Determinants of loan repayment decision among small holder farmers in southwestern Nigeria. Pakistan Journal of Social Sciences, 4(5), 677-686. Retrieved from http://www.medwelljournals.com/abstract/?doi=pjssci.2007.677.686

Onyeagocha, S. U. O., Chidebelu, S. A. N. D., Okorji, E. C., Ukoha, A. H., Osuji, M. N., \& Korie, O. C. (2012). Determinants of loan repayment of microfinance institutions in southeast states of Nigeria. International Journal of Social Science and Humanities, 1(1), 4-9. Retrieved from http://researchpub.org/journal/ijssh/number/vol1-no1/vol1-no1-1.pdf

Onyenucheya, F., \& Ukoha, O. (2007). Loan Repayment and Credit Worthiness of Farmers under the Nigerian Agricultural Cooperative and Rural Development Bank (NACRDB). Agricultural Journal, 2(2), 265-270. Retrieved from http://docsdrive.com/pdfs/medwelljournals/aj/2007/265-270.pdf

Osuntogun, C. A. (1997). The impact of specialized small holder credit programmes on farmers beneficiaries. A case study of first bank of Nigeria. African Review of Money Finance and Banking, 35-36.

Rahji, M. (2000). An analysis of the determinants of agricultural credit approval/loan size by commercial banks in southwestern Nigeria. Journal of Nigerian Development Studies, 6-25.

Shively, G. E. (1997). Consumption risk, farm characteristics and soil conservation adoption among low-income farmers in the Philippines. Agricultural Economics, 165-177. http://dx.doi.org/10.1016/S0169-5150(97)00023-6

Splett, N. S., Barry, P. J., Dixon, B. L., \& Ellinger, P. N. ( 1994). A joint experience and statistical approach to credit scoring. Agricultural Finance Review, 39-54.

Vogel, R. C. (1981). Rural financial market performance: Implication of low delinquency rates. American Journal of Agricultural Economics, 58-62. http://dx.doi.org/10.2307/1239811

\section{Copyrights}

Copyright for this article is retained by the author(s), with first publication rights granted to the journal.

This is an open-access article distributed under the terms and conditions of the Creative Commons Attribution license (http://creativecommons.org/licenses/by/3.0/). 